\title{
Improving the Quality of Thematic Learning Using Video-Based Media in Class II SDN Banyumanik 01 Semarang
}

\section{Erra May Hilda}

SD Negeri Banyumanik 01 Semarang

erra.mayhilda@gmail.com

Article History

accepted 01/11/2020

approved 08/11/2020

published 15/11/2020

\begin{abstract}
Media is an important component in improving the quality of learning. The purpose of this research is to improve the quality of thematic learning using video media. This research is a classroom action research (PTK) which is conducted in two cycles, each cycle consisting of planning, implementation, observation, and reflection stages. The subjects of this study were 28 students of class II SDN Banyumanik 01 Semarang. The research instruments were observation sheets, learning test results and documentation. Data analysis includes data reduction, data presentation, and drawing conclusions. The findings of this study are the use of instructional video media can improve the quality of students' thematic learning on the theme of my daily tasks in class II SDN Banyumanik 01 Semarang. The results showed that the percentage of student learning activities in cycle I 64.11\% increased in cycle II to $90.62 \%$ and the percentage of students who completed the learning outcomes in cycle I $36.4 \%$ increased in cycle II to $95.5 \%$.
\end{abstract}

Keywords: Quality of learning, Thematic, Video media

\begin{abstract}
Abstrak
Media merupakan salah satu komponen penting dalam meningkatkan kualitas pembelajaran. Tujuan penelitian ini adalah meningkatkan kualitas pembelajaran tematik menggunakan media video. Penelitian ini merupakan penelitian tindakan kelas (PTK) yang dilaksanakan dalam dua siklus, tiap siklus terdiri dari tahap perencanaan, pelaksanaan, observasi, dan refleksi. Subjek penelitian ini adalah peserta didik kelas II SDN Banyumanik 01 Semarang yang berjumlah 28 peserta didik. Instrumen penelitian adalah lembar observasi, hasil tes belajar dan dokumentasi. Analisis data meliputi reduksi data, penyajian data, dan penarikan kesimpulan. Temuan penelitian ini adalah penggunaan media video pembelajaran dapat meningkatkan kualitas pembelajaran tematik peserta didik pada tema tugasku sehari - hari di kelas II SDN Banyumanik 01 Semarang. Hasil penelitian ditunjukkan dengan persentase aktivitas belajar siswa pada siklus I $64,11 \%$ naik pada siklus II menjadi $90,62 \%$ dan persentase jumlah siswa yang tuntas dalam hasil belajar pada siklus I $36,4 \%$ naik pada siklus II menjadi $95,5 \%$.
\end{abstract}

Kata kunci: Kualitas pembelajaran, Tematik, Media video

Social, Humanities, and Education Studies (SHEs): Conference Series https://jurnal.uns.ac.id/shes

p-ISSN 2620-9284

e-ISSN 2620-9292 


\section{PENDAHULUAN}

Pelaksanaan pembelajaran tematik terpadu sesuai kurikulum 2013 merupakan upaya pemerintah untuk mengembangkan kemampuan peserta didik secara serentak dimana terdapat penggabungan beberapa muatan pelajaran menjadi satu dalam penyampaiannya. Standar isi kurikulum 2013 yang dijelaskan pada Lampiran Permendikbud no 64 tahun 2013 tentang Standar Isi, yaitu standar isi disesuaikan dengan substansi tujuan pendidikan nasional dalam domain sikap spiritual dan sikap sosial, pengetahuan, serta keterampilan.

Pembelajaran tematik di kelas II SDN Banyumanik 01 Semarang memiliki permasalahan tersendiri. Pemisahan antar mata pelajaran masih terlihat, bahkan terkadang guru masih menyebutkan mata pelajaran dalam proses pembelajaran tematik. Kegiatan pembelajaran tidak bertolak dari minat dan kebutuhan peserta didik karena pembelajaran masih berpusat pada guru (teacher centered). Materi yang disajikan kurang konstektual, karena guru hanya mengandalkan materi pada buku pegangan. Guru belum menggunakan media pembelajaran, sehingga informasi yang disampaikan masih bersifat abstrak. Hal tersebut ditunjukkan dengan hasil belajar pada penilaian evaluasi peserta didik yang menyisakan 10 dari 28 orang peserta didik belum mencapai KKM.

Rusman (2010:254) menyatakan bahwa pembelajaran tematik adalah "Pembelajaran terpadu yang menggunakan tema dan melibatkan beberapa mata pelajaran untuk memberikan pengalaman bermakna kepada peserta didik". Pembelajaran bermakna dalam tematik artinya peserta didik akan memahami konsep yang dipelajari dengan pengalaman langsung dan menghubungkannya dengan konsep lain yang telah dipahami. Etzioni menjelaskan kualitas dapat dimaknai dengan istilah mutu atau juga keefektifan (Daryanto, 2010:54). Sedangkan pengertian pembelajaran menurut Anitah (2008: 1.18) adalah proses interaksi peserta didik dengan guru dan sumber belajar pada suatu lingkungan belajar yang saling berkaitan, dan mempengaruhi dengan berorientasi pada tujuan. Pupuh (2010:67) menyatakan pembelajaran tematik membutuhkan peranan media pembelajaran. Media pembelajaran menempati posisi yang cukup penting sebagai salah satu komponen pembelajaran. Komunikasi tidak akan terjadi tanpa media dan proses pembelajaran sebagai proses komunikasi juga tidak akan bisa berlangsung secara optimal. Pemilihan media pun tidak sembarangan pilih. Media harus dipilih yang sekiranya benar-benar menarik minat peserta didik untuk belajar karena media termasuk penentu kualitas sebuah pembelajaran. Media Video mempunyai peranan tersendiri dalam bidang pendidikan khususnya untuk meningkatkan kualitas pengajaran dan pembelajaran. Beberapa kelebihan Media Video apabila digunakan dalam proses pembelajaran, yaitu mampu menyampaikan konsep yang kompleks secara visual dan dinamik, mampu menarik perhatian peserta didik dan menyampaikan pesan dengan baik, mampu digunakan membantu menyediakan pembelajaran secara maya, dapat menciptakan pembelajaran yang lebih menyenagkan, menarik perhatian, meningkatkan motivasi serta merangsang pemikiran peserta didi yang lebih berkesan. Selain itu juga memudahkan dalam proses penerapan konsep ataupun demonstrasi. Daryanto (2010: 79). 
Berdasar identifikasi penyebab masalah yang telah diuraikan pada latar belakang di atas, maka dapat dirumuskan masalah, yaitu bagaimanakah pelaksanaan pembelajaran tematik menggunakan Media video pembelajaran pada pembelajaran SubSubtema Tugasku Sehari - hari di Sekolah di Sekolahdi Kelas II SDN Banyumanik 01 dan apakah dengan penerapan media video pembelajaran dapat meningkatkan kompetensi belajar peserta didik melalui penilaian aspek pengetahuan dan keterampilan dalam pembelajaran SubSubtema Tugasku Sehari - hari di Sekolah di Sekolahdi Kelas II SDN Banyumanik 01.

Berdasarkan pada uraian di atas, penulis berupaya melakukan perbaikan pembelajaran melalui penelitian tindakan kelas dengan judul Peningkatan Kualitas Pembelajaran Tematik di kelas II SDN Banyumanik 01 Menggunakan Media berbasis Video Tahun Pelajaran 2020/ 2021. Tujuan penelitian ini adalah meningkatkan kualitas pembelajaran tematik pada tema tugasku sehari - hari dengan menerapkan media video.

\section{METODE}

Penelitian ini merupakan penelitian tindakan kelas (PTK) yang dilaksanakan dalam dua siklus. Setiap siklus dilaksanakan dalam dua kali pertemuan yang terdiri dari tahap perencanaan, pelaksanaan, observasi, dan refleksi. Subjek penelitian ini adalah peserta didik kelas II SD Negeri Banyumanik 01 Semarang tahun pelajaran 2020/2021 yang berjumlah 28 peserta didik.

Data yang dianalisis berupa data kualitatif yaitu pengamatan proses penggunaan media video dalam pembelajaran dan data kuantitatif yaitu hasil belajar mapel peserta didik. Teknik pengumpulan data menggunakan observasi dan tes. Uji validitas data menggunakan triangulasi teknik dan triangulasi sumber. Analisis data meliputi reduksi data, penyajian data, dan penarikan kesimpulan.

\section{HASIL DAN PEMBAHASAN}

Berdasarkan analisis hasil penelitian yang telah diuraikan maka pembahasan pada penelitian ini sebagai berikut.

\section{Hasil Peningkatan Aktivitas dalam Proses Pembelajaran Tematik Menggunakan Media Video}

Hasil penelitian menunjukkan peningkatan aktivitas proses pembelajaran yang dilakukan guru dan peserta didik. Terlihat pada tabel berikut:t.

Tabel 1. Hasil Proses Pembelajaran Tematik Menggunakan Media Video

\begin{tabular}{cccccccc}
\hline & $\begin{array}{c}\text { Jenis } \\
\text { Nktifitas }\end{array}$ & PT1 & PT2 & $\begin{array}{c}\text { Rata- } \\
\text { rata }\end{array}$ & PT1 & PT2 & $\begin{array}{c}\text { Rata- } \\
\text { rata }\end{array}$ \\
\cline { 3 - 7 } 1 & $\begin{array}{l}\text { Aktivitas } \\
\text { Guru }\end{array}$ & 62,50 & 75,00 & 68,75 & 90,63 & 96,88 & 93,76 \\
\hline $\begin{array}{l}\text { Aktivitas } \\
\text { Peserta } \\
\text { Didik }\end{array}$ & 56,25 & 71,88 & 64,07 & 87,50 & 93,75 & 90,63 \\
\hline
\end{tabular}

Keterangan:

PT1 = Pertemuan 1

PT2 = Pertemuan 2 


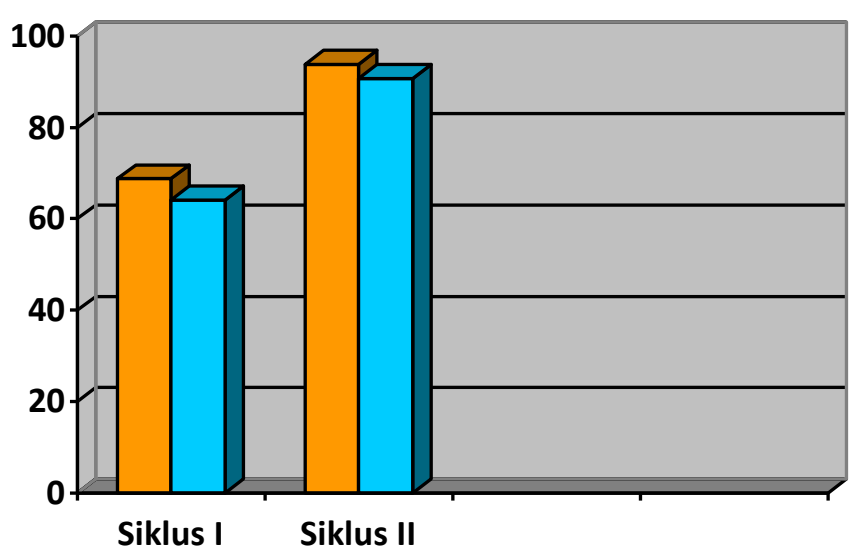

\section{$\square$ Aktivitas Guru \\ $\square$ Aktivitas Peserta Didik}

\section{Gambar 1. Hasil Belajar Kognitif dalam Pembelajaran Tematik Menggunakan Media Video}

Gambaran hasil belajar Kognitif dalam pembelajaran tematik menggunakan media video di kelas II Sekolah Dasar Negeri Banyumanik 01 Semarang dapat terlihat pada tabel 2 berikut ini:

Tabel 2. Hasil belajar Kognitif dalam Pembelajaran Tematik Menggunakan Media Video

\begin{tabular}{cccccc}
\hline \multirow{2}{*}{ No } & \multirow{2}{*}{ Mata Pelajaran } & \multicolumn{2}{c}{ Nilai Rata-rata } & \multicolumn{2}{c}{ Ketuntasan Klasikal } \\
\cline { 3 - 5 } & & Siklus I & Siklus II & Siklus I & Siklus II \\
\hline 1 & Bahasa Indonesia & 56,8 & 82,05 & $40,90 \%$ & $90,90 \%$ \\
\hline 2 & Matematika & 55,7 & 78,19 & $36,36 \%$ & $95,45 \%$ \\
\hline 3 & SBdP & 60,2 & 85,45 & $45,45 \%$ & $95,45 \%$
\end{tabular}

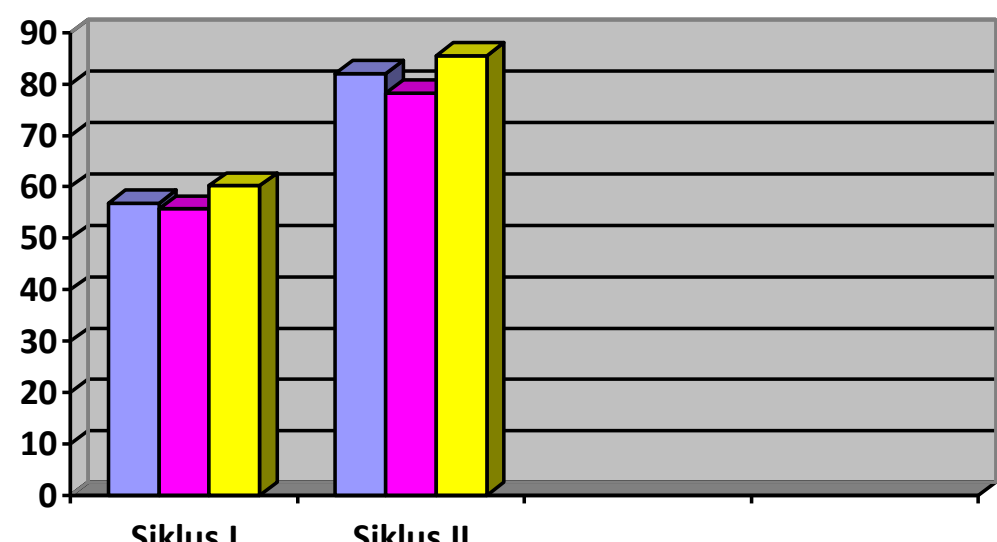

$\square$ Bahasa Indonesia
$\square$ Matematika
$\square$ SBdP

Gambar 2. Nilai Rata -rata 


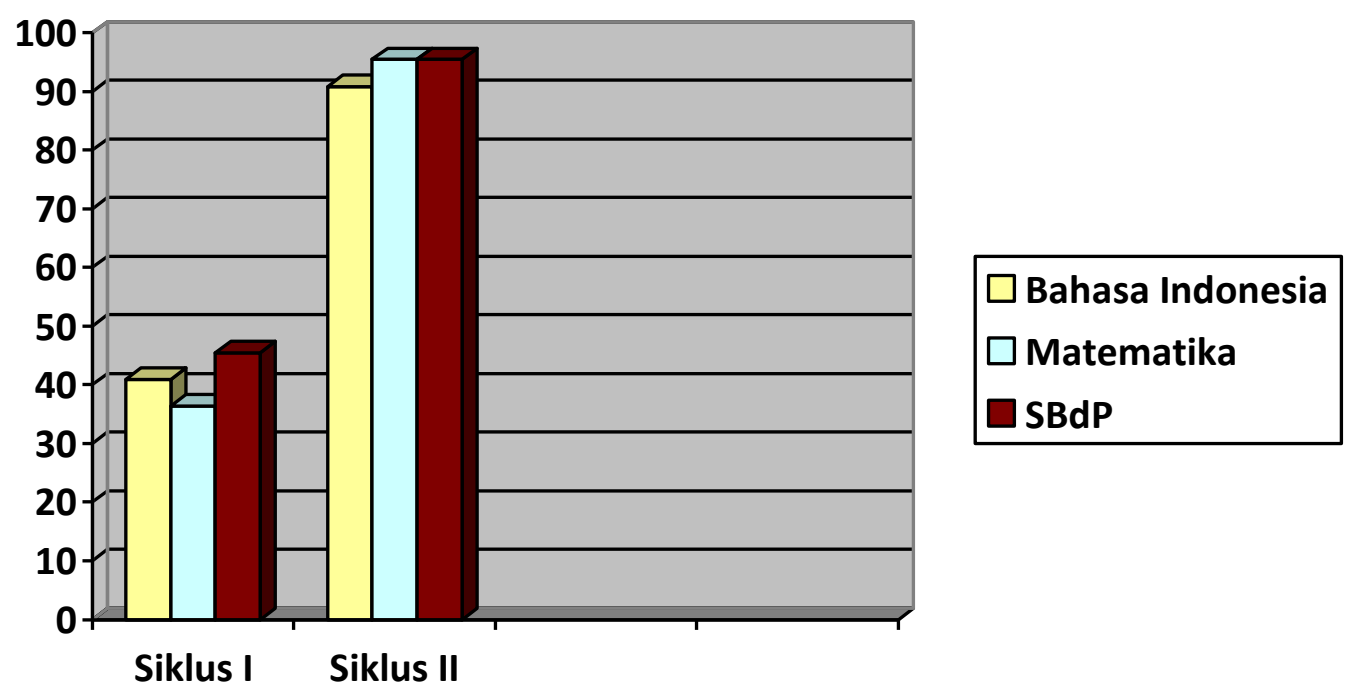

Gambar 3. Ketuntasan Klasikal

2Hasil Penilaian Pembelajaran Tematik Menggunakan Media Video

a. Hasil Proses pembelajaran Tematik pada Siklus I

1) Pertemuan pertama dari aspek guru perolehan skor adalah $62,50 \%$.

2) Pertemuan pertama dari aspek peserta didik perolehan skor adalah $56,25 \%$.

3) Pertemuan kedua dari aspek guru perolehan skor adalah $75,00 \%$.

4) Pertemuan kedua dari aspek peserta didik perolehan skor adalah $71,88 \%$.

Data penelitian Siklus I tampak 68,75\% untuk aktivitas guru dan 64,07\% untuk aktivitas siswa menunjukan bahwa proses pembelajaran tematik menggunakan media animasi belum mencapai indikator keberhasilan yang ditetapkan oleh peneliti yaitu lebih besar atau sama dengan $80 \%(\geq 80 \%)$. Begitu juga data penelitian $40,90 \%$ untuk persentase ketuntasan klasikal mata pelajaran bahasa Indonesia, $36,36 \%$ untuk persentase ketuntasan klasikal mata pelajaran Matematika, dan 45,45 untuk persentase ketuntasan klasikal mata pelajaran SBdP belum juga mencapai indikator keberhasilan yang ditetapkan oleh peneliti yaitu lebih besar atau sama dengan $75 \%(\geq 75 \%)$.

Dari catatan refleksi pembelajaran guru, pada siklus I masih ada kekurangan pada penggunaan media pembelajaran berbasis video, yaitu gambar tampilan video kurang jelas. Peserta didik menggunakan gawai yang berukuran kecil sehingga kualitas pembelajaran belum mengalami peningkatan yang berarti. Kemudian dari segi guru atau peneliti yaitu kurang maksimal dalam pengelolaan kelas maya. Peneliti masih kurang memberikan motivasi, penguatan, dan stimulus sehingga peserta didik kurang semangat dalam mengikuti kegiatan pembelajaran daring. Selain itu gangguan suara dari lingkungan luar juga mengganggu konsentrasi peserta didik yang sedang menyimak video pembelajaran kreatif dan interaktif.

Berdasarkan hasil pengamatan siklus I yang diperoleh, maka direncanakan untuk melakukan perbaikan pada pembelajaran berikutnya atau perbaikan selama proses pembelajaran pada siklus II. Pada siklus II nantinya guru harus memperhatikan kekurangan-kekurangan selama proses pembelajaran pada siklus I dan memperbaikinya pada siklus II. Untuk mengetahui hasil belajar peserta didik maka peneliti melakukan evaluasi terhadap peserta didik yang berkaitan dengan pembelajaran yang telah 
dilakukan.

b. Hasil Proses pembelajaran Tematik pada Siklus II

1) Pertemuan pertama dari aspek guru perolehan skor adalah $90,63 \%$.

2) Pertemuan pertama dari aspek peserta didik perolehan skor adalah $87,50 \%$.

3) Pertemuan kedua dari aspek guru perolehan skor adalah $96,88 \%$.

4) Pertemuan kedua dari aspek peserta didik perolehan skor adalah $93,75 \%$.

Hasil belajar peserta didik pada siklus II telah mencapai ketuntasan yang diharapkan, hal tersebut dapat dilihat pada nilai ketuntasan peserta didik. Jumlah persentase peserta didik yang memperoleh nilai ketuntasan individu untuk mata pelajaran Bahasa Indonesia 90,90\% dengan nilai rata-rata 82,05, untuk mata pelajaran Matematika 95,45\% dengan nilai rata- rata 78,19 , dan untuk mata pelajaran SBdP $95,45 \%$ dengan nilai rata-rata 85,45 . Jadi dapat disimpulkan bahwa guru berhasil dalam membelajarkan peserta didik yang dilihat dari hasil evaluasi.

Pada pelaksanaan siklus II ini guru memberikan banyak kesempatan kepada peserta didik untuk melakukan semua langkah pembelajaran dengan menggunakan media video. Pada siklus ini peserta didik dibawa pada suasana kelas yang baru dan menyenangkan seperti yang dikemukakan oleh Bruner dalam Isti (1999:3.27). "Proses belajar mengajar akan berjalan dengan baik dan kreatif jika guru memberikan kesempatan kepada peserta didik untuk menentukan dan melakukan sesuatu".

Berdasarkan analisis penelitian siklus II, penerapan media video sudah sangat baik dalam pembelajaran tematik sehingga mampu meningkatkan kemampuan peserta didik dalam pemahaman konsep, (Agustiningsih: 2015) Hal ini dibuktikan dari hasil belajar peserta didik. Hasil pengamatan siklus II yang diperoleh data bahwa pelaksanaan siklus II sudah baik dan guru sudah berhasil menggunakan media video untuk meningkatkan hasil belajar peserta didik pada pembelajaran tematik tema tugasku sehari- hari di Kelas II.

Guru sebagai pengajar dan pendidik memiliki kewajiban dalam membelajarkan peserta didik dengan memperhatikan beberapa aspek dalam pembelajaran antara lain kesesuaian dengan kebutuhan dan perkembangan peserta didik, serta memperhatikan keberhasilan peserta didik dalam memahami suatu materi pembelajaran disesuaikan dengan karakteristik dan tingkat kemampuan masing - masing. Guru berperan sebagai fasilitator dan motivator. Dalam membelajarkan peserta didik, guru harus memilih dan menggunakan berbagai strategi agar pembelajaran menjadi bermakna. (Rusman:2013) Oleh karena itu guru harus melakukan perbaikan dalam pelaksanaan pembelajaran serta perbaikan perangkat pembelajaran yang lebih inovatif. Dengan demikian kualitas pembelajaran akan meningkat diikuti oleh meningkatnya hasil belajar peserta didik pada tema tersebut.

\section{SIMPULAN}

Peneliti melakukan pelaksanaan pembelajaran tematik menggunakan media video pembelajaran dengan tema tugasku sehari - hari di sekolah, dengan urutan sebagai berikut:1)Menggunakan platform Zoomeeting, 2)Menerapkan langkah-langkah 
penggunaan media video pembelajaran, 3) Menggunakan media video pembelajaran, 3) Menggunakan berbagai macam metode pembelajaran seperti ceramah, pemberian tugas, demonstrasi, dan tanya jawab, 4)Menggunakan LKPD, 5) Menciptakan suasana yang kondusif.

Penilaian pembelajaran tematik menggunakan media video pembelajaran dengan tema tugasku sehari - hari di sekolah, peneliti melakukan kegiatan sebagai berikut:1) Penilaian proses pembelajaran, pengambilan datanya menggunakan lembar observasi, 2) Penilaian hasil belajar mencakup tiga kompetensi kognitif, afektif, dan psikomotor, 3) Dalam proses pembelajaran tidak terlihat pemisahan mata pelajaran tetapi dalam penilaian hasil belajar tetap menilai per mata pelajaran.

Penggunaan media video pembelajaran dalam pembelajaran tematik dengan tema tugasku sehari - hari di kelas II SDN Banyumanik 01 Semarang, dapat meningkatkan kualitas pembelajaran dari segi proses pembelajaran dan hasil belajar. Hal ini dapat dilihat dari peningkatan persentase aktivitas belajar siswa pada siklus I $64,11 \%$ naik pada siklus II menjadi $90,62 \%$ dan persentase jumlah siswa yang tuntas dalam hasil belajar pada siklus I $36,4 \%$ naik pada siklus II menjadi $95,5 \%$ serta nilai rata-rata pada siklus I 62.3 naik pada siklus II menjadi 83,7.

\section{DAFTAR PUSTAKA}

Agustiningsih. (2015). Video Sebagai Alternatif Media Pembelajaran Dalam Rangka Mendukung Keberhasilan Penerapan Kurikulum 2013 Di SD, Jurnal Pedagogia, 4 (1) : 2089-3833.

Daryanto. (2010). Media Pembelajaran. Yogyakarta: Gava media.

Handika, KD (2017). Pentingnya media dalam meningkatkan kualitas pembelajaran peserta didik di sekolah dasar.

Fathurrohman, Pupuh. (2010). Strategi Belajar Mengajar (Melalui Penanaman Konsep Umum dan Konsep Islami). Bandung: Refika Aditama

Rusman. 2010. Model-Model Pembelajaran Mengembangkan Profesional Guru. Jakarta: Raja Grafindo Persada

Siregar, E., (2014), Teori Belajar dan Pembelajaran, Ghalia Indonesia, Bogor

Slameto, (2013), Belajar dan Faktor-faktor yang Mempengaruhinya, Rineka Cipta, Jakarta

Trianto. 2010. Mengembangkan Model Pembelajaran Tematik. Jakarta: Prestasi Pustaka. 